\title{
PENGARUH POLA ASUH ORANGTUA TERHADAP SIKAP SISWA DALAM PELAKSANAAN TATA TERTIB SEKOLAH (Studi Eks-post facto di Kelas VIII SMP Al Kautsar Bandar Lampung Tahun Pelajaran 2013/2014)
}

\author{
Fatwiasih Al Humaira ${ }^{1}$ \\ Dra. Dewi Justitia, M.Pd., Kons ${ }^{2}$ \\ Drs. Djunaedi, M.Pd ${ }^{3}$
}

\begin{abstract}
Abstrak
Penelitian ini bertujuan untuk mengetahui gambaran sikap terhadap pelaksanaan tata tertib sekolah siswa yang diasuh dengan pola asuh demokratis, otoriter, dan permisif serta untuk mengetahui perbedaan pengaruh pola asuh demokratis, otoriter, dan permisif terhadap sikap siswa dalam pelaksanaan tata tertib sekolah. Penelitian ini menggunakan metode penelitian ex- post facto. Instrumen yang digunakan yaitu instrumen sikap. Populasi peneitian berjumlah 300 orang siswa kelas VIII. Pengambilan sampel menggunakan teknik proportionate random sampling dengan jumlah sampel sebanyak 60 orang siswa. Berdasarkan hasil penelitian diketahui kecenderungan siswa dengan pola asuh demokratis bersikap positif sebesar $9.09 \%$, netral $72.73 \%$, dan negatif sebesar $18.18 \%$. Sedangkan siswa dengan pola asuh otoriter yang memiliki kecenderungan sikap positif 10\%, netral 75\%, dan negatif sebesar 15\%. Untuk siswa dengan pola asuh permisif memiliki sikap positif sebesar $33.33 \%$, netral $33.33 \%$, dan negatif 33.34\%. Berdasarkan hasil uji hipotesis menggunakan ANAVA satu jalan didapatkan nilai sig. 0.00 dengan $\alpha 0.05$ dan dapat diartikan bahwa terdapat perbedaan pengaruh pola asuh demokratis, otoriter, dan permisif terhadap sikap siswa dalam pelaksanaan tata tertib sekolah. Selanjutnya berdasarkan hasil uji lanjutan t-Dunnet didapatkan hasil bahwa pengaruh pola asuh demokratis secara signifikan lebih tinggi dari pengaruh pola asuh otoriter, pengaruh pola asuh demokratis secara signifikan lebih tinggi dari pengaruh pola asuh permisif, dan pengaruh pola asuh otoriter secara signifikan lebih tinggi daripada pengaruh pola asuh permisif. Hasil Penelitian ini dapat digunakan oleh pihak sekolah khususnya guru Bimbingan dan Konseling untuk meningkatkan sikap positif siswanya. Guru Bimbingan dan Konseling dapat menyusun satuan layanan (satlan) bimbingan klasikal dengan materi tentang pentingnya pelaksanaan tata tertib sekolah, ataupun melaksanakan bimbingan kelompok membahas topik sikap positif terhadap pelaksanaan tata tertib sekolah.
\end{abstract}

Kata Kunci: Pola Asuh Orangtua, Sikap Siswa Kelas VIII SMP dalam Pelaksanaan Tata Tertib Sekolah.

\footnotetext{
1 Mahasiswa Jurusan Bimbingan dan Konseling FIP UNJ, fatwiasihhumaira91@gmail.com

2 Dosen Bimbingan dan Konseling FIP UNJ,

3 Dosen Bimbingan dan Konseling FIP UNJ,
} 


\section{Pendahuluan}

Pendidikan pada hakikatnya adalah usaha sadar untuk mengembangkan kepribadian dan kemampuan siswa didalam maupun diluar sekolah. Pendidikan nasional berfungsi mengembangkan kemampuan dan membentuk watak serta peradaban bangsa yang bermartabat dalam rangka mencerdaskan kehidupan bangsa, bertujuan untuk berkembangnya potensi siswa agar menjadi manusia yang beriman dan bertaqwa kepada tuhan yang maha Esa, berakhlak mulia, sehat, berilmu, cakap, kreatif, mandiri, dan menjadi warga negara yang demokratis serta bertanggung jawab.

Sekolah sebagai salah satu lembaga penyelenggara pendidikan formal mempunyai peran dan tanggung jawab yang besar untuk mendidik, membimbing dan mengarahkan siswa sesuai dengan tujuan pendidikan yang diharapkan. Salah satu upaya yang dapat dilakukan sekolah untuk mewujudkan tujuan pendidikan pada setiap siswanya adalah dengan menegakkan kedisiplinan melalui pelaksanaan tata tertib sekolah

Menurut Zubaedi (2012), pola asuh dapat didefinisikan sebagai pola interaksi antara anak dan orangtuanya yang meliputi pemenuhan kebutuhan fisik (seperti makan dan minum) dan keutuhan psikologis (seperti rasa aman dan kasih sayang), serta sosialisasi norma-norma yang berlaku di masyarakat agar anak dapat hidup selaras dengan lingkungannya. Dengan kata lain, pola asuh juga meliputi pola interaksi orangtua dengan anak dalam rangka pendidikan dalam keluarga yang diduga dapat mempengaruhi cara anak bertindak maupun bersikap dalam kehidupannya tidak terlepas pula dalam kehidupan anak ketika disekolah

Melalui angket sikap terhadap pelaksanaan tata tertib yang diberikan pada 14 siswa kelas VIII SMP Al Kautsar Bandar Lampung yang paling banyak melakukan pelanggaran tata tertib sekolah pada studi pendahuluan dapat diketahui bahwa siswa dengan kecenderungan sikap positif sebanyak 3 orang (21.4\%); kategori netral sebanyak 8 orang (57.2\%); dan kategori negatif sebanyak 3 orang $(21.4 \%)$. Sehingga dapat dimaknai bahwa para siswa ini memiliki sikap yang berbeda-beda meski cenderung kurang positif terhadap pelaksanaan tata tertib yang ada. Peneliti juga menyebarkan kuesioner pola asuh orangtua kepada 300 orang siswa. Dari kuesioner tersebut diketahui, bahwa siswa yang diasuh secara demokratis sebanyak 108 orang, siswa yang diasuh secara otoriter sebanyak 100, dan siswa yang diasuh secara permisif sebanyak 92 orang.

Berdasarkan hasil studi pendahuluan yang diperoleh dan latar belakang yang peneliti paparkan, serta dikuatkan dengan referensi di atas maka peneliti menganggap perlu untuk melakukan penelitian. Rumusan penelitian ini ialah "Apakah ada perbedaan pengaruh pola asuh demokratis, permisif, dan otoriter terhadap sikap siswa kelas VIII pada pelaksanaan tata tertib sekolah di SMP Al Kautsar Bandar Lampung tahun pelajaran 2013/2014?". Pene-litian ini bertujuan untuk mengetahui gambaran sikap siswa kelas VIII dalam pelaksanaan tata tertib sekolah yang diasuh dengan pola asuh demokratis, otoriter, dan permisif ; mengetahui ada tidaknya perbedaan pengaruh pola asuh demokratis, otoriter, dan permisif terhadap sikap siswa kelas VIII dalam pelaksanaan tata tertib sekolah.

\section{Kajian Teori.}

Sikap adalah salah satu istilah bidang psikologi yang berhubungan dengan persepsi dan tingkah laku. atau situasi yang dihadapi. Menurut Saifuddin Azwar (2002), sikap adalah salah satu unsur kepribadian yang harus dimiliki seseorang untuk menentukan tindakannya dan bertingkah laku terhadap suatu objek disertai dengan perasaan positif dan negatif. Reaksi seseorang terhadap suatu kejadian atau situasi bisa dikatakan adalah sikap. Sikap seseorang tersebut dilakukan tak hanya berdasarkan pengetahuan yang dimiliki oleh orang tersebut, tetapi juga hal yang lebih esensial dalam hal sikap adalah perasaan atau emosi dari orang tersebut.

Dapat disimpulkan pula bahwa sikap pada dasarnya merupakan hasil dari proses sosialisasi dan interaksi seseorang dengan lingkungannya, yang merupakan perwujudan dari pikiran, perasaan seseorang serta penilaian terhadap obyek, yang didasarkan pada pengetahuan, pemahaman, pendapat dan keyakinan dan gagasan-gagasan terhadap suatu obyek sehingga menghasilkan suatu kecenderungan untuk bertindak pada suatu obyek. Dengan demikian sikap adalah kecenderungan individu menanggapi secara positif atau negatif terhadap obyek si- 
kap ditinjau dari dimensi kognisi, afeksi dan konatif. Komponen sikap terdiri atas tiga bagian yang saling menunjang yaitu:

1) Komponen kognitif, merupakan representasi apa yang dipercaya oleh individu pemilik sikap, komponen kognitif berisi kepercayaan stereotipe yang dimiliki individu mengenai sesuatu dapat disamakan penanganan (opini) terutama apabila, menyangkut masalah suatu problem yang kontroversial.

2) Komponen afektif, merupakan perasaan yang menyangkut aspek emosional. Aspek emosional inilah yang biasanya berakar paling dalam sebagai komponen sikap dan merupakan aspek yang paling bertahan terhadap pengaruh-pengaruh yang mungkin adalah mengubah sikap se-seorang komponen afektif disamakan dengan perasaan yang dimilki seseorang terhadap se-suatu.

3) Komponen konatif, merupakan aspek kecenderungan berperilaku tertentu sesuai dengan sikap yang dimiliki oleh seseorang. Komponen ini, berisi tendensi atau kecenderungan untuk betindak/bereaksi terhadap sesuatu dengan cara-cara tertentu. Dan berkait dengan objek yang dihadapinya adalah logis untuk mengharapkan bahwa sikap sesorang adalah dicerminkan dalam bentuk tendensi perilaku.

Menurut Muhammad Rifa'i (2011), Tata tertib sekolah merupakan satu kesatuan yang tidak dapat dipisahkan antara yang satu dengan yang lain sebagai aturan yang berlaku di sekolah agar pro-ses pendidikan dapat berlangsung secara efektif dan efisien. Selanjutnya Indrakusumah (1973), mengartikan tata tertib sebagai "sederetan peraturan yang harus ditaati dalam suatu situasi atau dalam tatakehidupan tertentu". Berdasarkan pendapat para ahli di atas, tata tertib merupakan sekumpulan aturan yang dibuat secara tertulis dan mengikat yang harus dipatuhi setiap warga sekolah tempat berlangsungnya proses belajar mengajar. Pelaksanaan tata tertib sekolah akan berjalan dengan baik jika aparat sekolah, guru, dan terutama siswa saling mendukung tata tertib sekolah.

Suharsimi Arikunto (1990) berpendapat bahwa, pada hakikatnya semua pelaksanaan tata tertib sekolah dapat dilihat dari tiga unsur, yaitu:
1) Tingkah laku yang diharuskan dan yang dilarang.

2) Sanksi atau akibat yang menjadi tanggung jawab pelanggar peraturan.

3) Prosedur untuk menyampaikan tata tertib kepada subjek yang dikenai tata tertib tersebut.

Menurut Papalia (2004), pola asuh adalah cara orangtua membesarkan anak dengan memenuhi kebutuhan anak, memberi perlindungan, mendidik anak, serta mempengaruhi tingkah laku anak dalam kehidupan sehari-hari. Sejalan dengan pengertian di atas, Brooks (1991), mengatakan pengasuhan adalah suatu proses yang di dalamnya terdapat unsur memelihara, melindungi, dan mengarahkan anak selama masa perkembangannya. Berdasarkan penjelasan di atas, maka definisi pola asuh orangtua yang digunakan dalam penelitian ini adalah suatu proses interaksi yang terjadi antara orangtua dan anak, yang meliputi mendidik, memelihara, melindungi, dan mengarahkan tingkah laku anak selama masa perkembangan anak tersebut.

Menurut Baumrind (1966), membagi pola asuh menjadi tiga tipe yaitu: Authoritarian, Permissive dan Authoritative.

\section{1) Authoritarian / otoriter}

Orangtua berusaha membentuk, mengendalikan, serta mengevaluasi tingkah laku anak sesuai dengan standar tingkah laku yang ditetapkan orangtua. Dalam pola pengasuhan ini orangtua berlaku sangat ketat dan mengontrol anak tapi kurang memiliki kedekatan dan komunikasi berpusat pada orangtua.

2) Permissive / permisif

Pada pola pengasuhan permisif, orangtua bersikap responsif terhadap kebutuhan anak tetapi mereka menghindari segala bentuk tuntutan ataupun kontrol kepada anak-anak. Selain itu orangtua juga bersikap tidak menghukum dan menerima serta menyetujui apa saja yang dilakukan anak. Orangtua seperti ini tetap menyayangi anak tetapi menghindari pemberian perintah kepada anak.

3) Authoritative / Demokratis

Pola asuh Authoritative orangtua menggunakan pendekatan rasional dan demokratis. Orangtua menawarkan keakraban dan menerima tingkah 
laku asertif anak mengenai peraturan, norma dan nilai-nilai. Orangtua dengan pola pengasuhan seperti ini mau mendengarkan pendapat anak, menerangkan peraturan dala keluarga, dan menerangkan norma dan nilai yang dianut. Selain itu orangtua juga dapat bernegosiasi dengan anak.

\section{Metode Penelitian.}

Metode penelitian dalam penelitian ini adalah metode Eks - post facto. Penelitian dilakukan di SMP Al Kautsar Bandar Lampung. Sekolah ini beralamat di Jl. Soekarno Hatta Rajabasa Bandar Lampung. Penelitian berlangsung dari bulan November 2103 - Mei 2014. Teknik pengambilan sampling yang digunakan adalah proportionate random sampling. Mengacu hasil studi pendahuluan dan sebaran instrumen kepada 300 siswa kelas VIII SMP Al Kautsar Bandar Lampung, terdapat 108 orang dengan pola asuh demokratis, 100 orang siswa dengan pola asuh otoriter, dan 82 orang siswa dengan pola asuh permisif. Peneliti mengambil sampel 20\% dari jumlah disetiap populasi yaitu 22 orang siswa dengan pola asuh demokratis, 20 orang siswa dengan pola asuh otoriter, dan 18 orang dengan pola asuh permisif.

Alat pengumpul data berupa instrumen yang dikembangkan dari teori Saifuddin Azwar dan tata tertib di SMP Al Kautsar Bandar Lampung. Dalam menggunakan instrumen penelitian ini menggunakan pedoman skoring dengan skala pengukuran Likert. Dari 30 butir item instrumen yang dikembangkan oleh peneliti, kemudian uji kesahihan (Validitas) diperoleh sebanyak 28 butir item yang valid dan sebanyak 2 butir item drop. Selain itu, peneliti juga melakukan validitas konstrak berupa justifikasi ahli (judgement expert) yang dikonsultasikan kepada kedua dosen pembimbing peneliti.

Setelah dilakukan uji validitas dan didapatkan jumlah butir yang valid sebanyak 28 butir kemudian butir yang valid di uji reliabilitasnya dan didapatkan data bahwa instrumen ini cukup reliabel sebesar 0.89 , peneliti mengolah data secara manual.

Pengujian hipotesis dilakukan untuk mengetahui perbedaan pengaruh pola asuh demokratis, otoriter, dan permisif terhadap sikap siswa dalam pelaksanaan tata tertib sekolah. Dalam penelitian ini uji hipotesis dilakukan dengan menggunakan teknik
One Way Analyse of Variance (ANOVA). Selanjutnya untuk uji lanjutan (post hoc test) menggunakan uji t-Dunnet.

\section{Hasil dan Pembahasan.}

Berdasarkan hasil penelitian ada sebanyak 8 orang siswa atau $13.6 \%$ berada pada kategori sikap terhadap pelaksanaan tata tertib sekolah positif. Pada kategori sikap terhadap pelaksanaan tata tertib sekolah netral diketahui persentase sebesar 73\% artinya ada 44 orang siswa yang bersikap netral. Untuk kategori negatif diketahui terdapat 8 orang siswa atau sebesar $13.5 \%$. Untuk lebih jelasnya data di atas dapat di visualisasikan kedalam grafik di bawah ini:

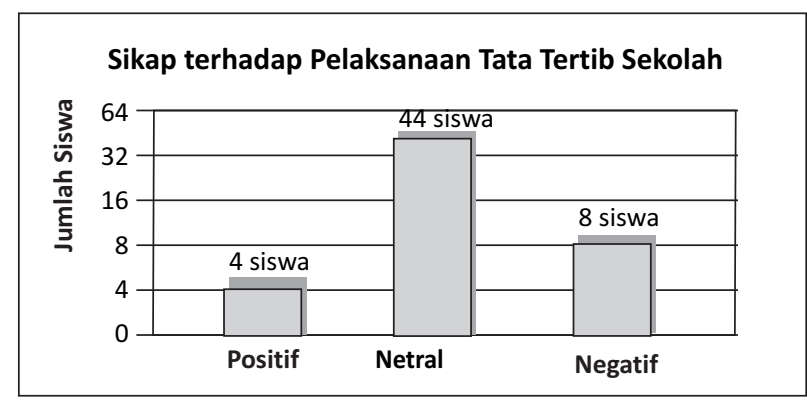

Grafik 4.1

Sikap terhadap Pelaksanaan Tata Tertib Sekolah Siswa di SMP AI Kautsar Bandar Lampung Tahun Pelajaran 2013/2014

Variabel pola asuh demokratis dengan sampel sebanyak 22 orang, terdapat 2 siswa atau 9.09\% kategori sikap dalam pelaksanaan tata tertib sekolah positif, untuk siswa yang berada di kategori netral berjumlah 16 orang siswa atau $72.73 \%$, dan terdapat $18.18 \%$ atau sebesar 4 orang siswa berada di kategori negatif. Pada variabel pola asuh otoriter dengan sampel sebanyak 20 orang, terdapat 2 orang siswa atau $10 \%$ yang berada pada kategori sikap terhadap pelaksanaan tata tertib sekolah positif, pada kategori sikap terhadap pelaksanaan tata tertib sekolah netral diketahui persentase sebesar $75 \%$ artinya ada 15 siswa, dan terdapat $15 \%$ atau sebesar 3 orang siswa berada di kategori negatif. Untuk variabel pola asuh permisif dengan jumlah sampel 18 orang, terdapat 6 orang siswa atau $33.33 \%$ berada pada kategori sikap terhadap pelaksanaan tata tertib sekolah positif, kategori sikap terhadap pelaksanaan tata tertib sekolah 
netral diketahui ada 6 siswa atau sebesar 33.34\%, dan terdapat $33,33 \%$ atau sebanyak 6 orang siswa berada di kategori negatif. Untuk lebih jelasnya data di atas dapat di visualisasikan kedalam grafik di bawah ini:

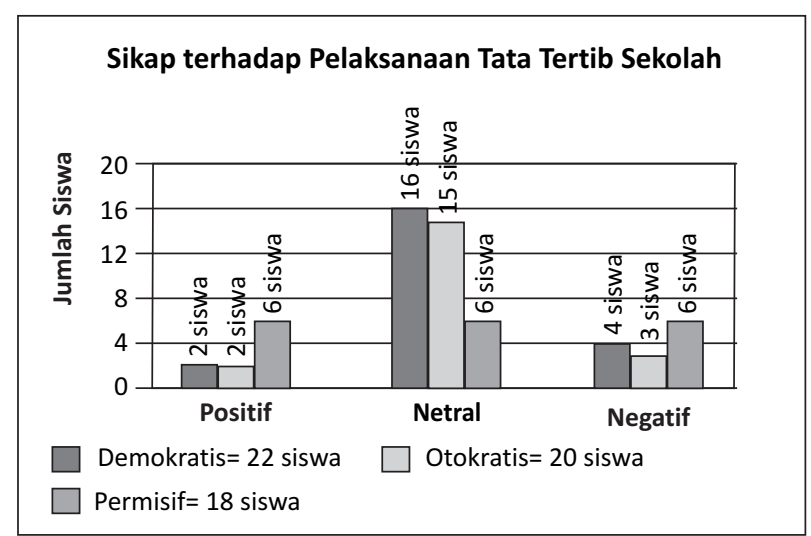

Grafik 4.2

Sikap terhadap Pelaksanaan Tata Tertib Sekolah Siswa Berdasarkan Pola Asuh Orangtua di SMP AI Kautsar Bandar Lampung Tahun Pelajaran 2013/2014

Berdasarkan grafik di atas dapat dimaknai bahwa siswa kelas VIII SMP Al Kautsar Bandar Lampung memiliki kecenderungan bersikap netral baik siswa yang diasuh dengan pola asuh demokratis, otoriter, dan permisif terhadap pelaksanaan tata tertib sekolah artinya dalam menyikap tingkah laku yang dilarang dan diharuskan, sanksi, serta prosedur penyampaian aturan tidak bersikap mendukung maupun menolak secara tegas terhadap pelaksanaan tata tertib sekolah.

Hasil penelitian berdasarkan hasil uji hipotesis menunjukkan bahwa signifikansi sebesar 0.00 dan $\alpha$ $=0,05$ menunjukkan bahwa Sig. $<$ dari $\alpha$ serta perhitungan koefisien determinasi $(\mathrm{R} 2)=0,2818$ atau $28,18 \%$. Agar Ha diterima syaratnya adalah Sig. < $\alpha$. Hal ini berarti terdapat perbedaan pada taraf $5 \%$. Dengan demikian Ha diterima dan $\mathrm{H} 0$ ditolak. Maka dapat dimaknai, terdapat perbedaan pengaruh pola asuh demokratis, otoriter, dan permisif terhadap sikap siswa dalam pelaksanaan tata tertib sekolah.

Berdasarkan hasil perhitungan uji lanjut (post hoc test) dengan t-Dunnet didapatkan hasil bahwa;

a. to $(\mathrm{D}-\mathrm{O})=2.08>$ ttabel $=1.68($ pada $\alpha=0.05)$

b. to $(\mathrm{D}-\mathrm{P})=14.00>$ ttabel $=1.68($ pada $\alpha=0.05)$

c. to $(\mathrm{O}-\mathrm{P})=11.52>$ ttabel $=1.68($ pada $\alpha=0.05)$.
Dapat dijabarkan bahwa pengaruh pola asuh demokratis terhadap sikap siswa pada pelaksanaan tata tertib sekolah secara signifikan lebih tinggi daripada pengaruh pola asuh otoriter terhadap sikap siswa pada pelaksanaan tata tertib sekolah. Diketahui juga bahwa pengaruh pola asuh demokratis terhadap sikap siswa pada pelaksanaan tata tertib sekolah secara signifikan lebih tinggi daripada pengaruh pola asuh permisif terhadap sikap siswa pada pelaksanaan tata tertib sekolah. Serta pengaruh pola asuh otoriter terhadap sikap siswa pada pelaksanaan tata tertib sekolah secara signifikan lebih tinggi daripada pengaruh pola asuh permisif terhadap sikap siswa pada pelaksanaan tata tertib sekolah.

\section{Simpulan dan Saran}

Berdasarkan hasil penelitian dan analisis hasil penelitian yang telah dilakukan peneliti maka dapat ditarik kesimpulan bahwa ada perbedaan pengaruh pola asuh demokratis, otoriter, dan permisif terhadap sikap siswa dalam pelaksanaan tata tertib sekolah. Variabel pola asuh orangtua dapat mempengaruhi $28.21 \%$ variansi sikap siswa terhadap pelaksanaan tata tertib sekolah. Pengaruh pola asuh demokratis secara signifikan lebih tinggi daripada pengaruh pola asuh otoriter maupun permisif terhadap sikap siswa dalam pelaksanaan tata tertib sekolah.

Kepala Sekolah berkoordinasi dengan para guru dan siswa dalam merumuskan peraturan ataupun tata tertib sekolah yang akan diberlakukan. Kepala sekolah juga berkoordinasi dengan para orangtua/ wali murid dengan mengadakan pertemuan terkait dengan pentingnya pola asuh orangtua. Dapat menjadikan penelitian ini sebagai bahan informasi dalam menyusun satuan layanan (satlan) bimbingan klasikal dengan materi tentang pentingnya pelaksanaan tata tertib sekolah, ataupun melaksanakan bimbingan kelompok membahas topik sikap positif terhadap pelaksanaan tata tertib sekolah. Penelitian selanjutnya diharapkan dapat meneliti dengan sampel yang lebih banyak sehingga hasil penelitian dapat digeneralisasikan secara lebih luas. 


\section{Daftar Pustaka}

Arikunto, Suharsimi. (1990). Manejemen Pengajaran Secara Manusiawi. Jakarta: Rineka Cipta

Azwar, Saifuddin. (2002). Sikap Manusia: Teori dan Pengukurannya. Yogyakarta: Pustaka Pelajar

Baumrind, Diana. (1966) Effects of Authoritative Parental Control on Child Behavior, 37(4). Child Development Journal. 1966

Brooks, Jane B. (1991) The Process of Parenting. California: Mayfield Publishing Company
Indrakusumah. (1973). Fungsi Tata Tertib Sekolah, Jakarta

Papalia, D.E. (2004). Human Development. New York: Mc Graw Hill

Rifa'i, Muhammad. (2011). Sosiologi Pendidikan. Yogyakarta: Ar-Ruzz Media

Zubaedi. (2012). Desain Pendidikan Karakter. Jakarta: Kencana 